\title{
FATE WRITTEN ON THE FOREHEAD IN SERBIAN ORAL NARRATIVES
}

\author{
Nemanja Radulović
}

\begin{abstract}
This paper examines narratives about fate from the Serbian corpus, as well as beliefs related to them. A characteristic motif is that the demons of fate write fate on people's forehead. Such motifs and beliefs are also encountered elsewhere on the Balkans, especially in the areas that were under Turkish influence (Greece, Albania, Bulgaria), so it is undoubtedly a Balkanism. The presence of the motif among Turks and Arabs indicates oriental roots. However, the bottom source seems to be India where the oldest examples have been recorded. Classical Sanskrit literature (including tales collections, such as Hitopadeśa, Pañcatantra, Vikramacarita, Vetalapañcavimśati) provides numerous examples of this motif. This is certainly not a source but only a testimony of the presence of the motif. The contemporary rituals and views of modern popular Hinduism testify to its connection to belief. It seems that beliefs and narratives migrated via Muslim culture to the Balkans. Methodologically speaking, this is not a matter of going back to Benfey or Cosquin, but an example of the importance of regions and cultural contacts. The motif and belief seem to be close to the phraseologism "written on the forehead", but the conclusion is that they have different origins; while the idiom that is present in many languages comes from the idea of "reading", discerning one's nature, the narrative motif clearly has a specifically Oriental origin and is linked to living belief.
\end{abstract}

Keywords: Balkans, belief, fate, India, Islam, migrations, narratives, phraseologisms, regions

In oral tradition about fate (ATU 930, 931, 934) spoken in the southern Slavic and Balkan regions, the motif of written fate can often be found. This motif emerges in two ways. In one group it concerns an unspecified writing of fate or the fate that is written in books. In the second group, the forehead is the place where fate is written. For instance, in type ATU 930 it is written on a child's forehead that the child will eat a wealthy man's property (Šaulić 1931, no. 98). In type ATU 934 death by a turtle is written on the forehead (Đordevic 1988, no. 120). In the latter example, a man is trying to escape from a personified plague. When she catches him, she looks at his forehead and says: "It is not fated that I should kill you. You were running from me in vain and I was chasing you in vain. You'll be killed by a turtle". Later, as he mows a field, his scythe strikes 
a turtle, ricochets off its shell and wounds his own leg. As a result, he dies of blood poisoning. In yet another example (Javor 1882) belief is blurred: three babies are born, and the first one has it written on his forehead that he will earn a certain amount of money.

This motif is not a stable part of any particular type of tale (as Uriah's letter is a stable part of AT 930). It can rather be found in the few types mentioned above, so it is mentioned only as a variant of a fate determination (in most cases the Fates speak). Also, the motif does not belong to the fictional aspect of oral narratives, but originates from beliefs. Moreover, this separation exists in the belief itself. The motif of a book of fate, i.e., writing fate in different books, will be left aside here. I can only note that it is very common, and it can be found as highly elaborated (the Fates do not have only one book, but a home full of books or notebooks) (Cepenkov 1972a, no. 112), and the writing of fate in books, tablets, or leaves occurred in old Rome, Babylon, and in Turkish and Finno-Ugric cultures. As for Indo-Europeans, to whom writing itself was yet unknown (West 2007: 386), the motif probably came from the same source as literacy, from the Near East.

The occasional mention of calendars or views about literacy in folk prose in general signals the penetration of contemporaneity and the spread of literacy and schools (Röhrich 1964 [1956]: 191-193), and should be differentiated from the aforementioned examples. However, the motif of written fate has nothing to do with that. It has a different, more ancient origin. The difference can be easily seen if we compare Croatian and Macedonian folktales. The former lack representations of the motif of writing on the forehead, although literacy is quite often present in them. The same is true of the folktales of Serbs from Croatia. Signs of literacy, which are more frequent in them than in Serbian folktales from the areas that were under Turkish influence, are connected to everyday life. In Macedonian folktales, although real signs of literacy can be found (e.g., mentions of school), the specific motif of writing fate is also present. The context itself, which is connected to pagan, mythological beliefs, indicates its different origin.

Similar to this motif are tales and lore about a skull with an inscription on the forehead, which are related to Emperor Constantine and the origin of Constantinople, and have also been identified in the book Tales of a Parrot (Tuti-name) (night 25) (Nahshabi 1979: 177). A man finds a skull with an inscription saying (Veljić 1900, no.7) (or it speaks itself) that it has killed many people; he burns the skull, but his daughter finds it, miraculously conceives and gives birth to a boy who, after several adventures, becomes emperor and establishes Constantinople. In the southern Slavic region this plot also occurs in a form of epic poems (Milošević-Đorđević 1971: 112-127). 
However, these will also be taken out of consideration here because a similarity in motif still does not classify this group as a whole in tales about fate. The story parallels another one in Livy (1:55), favouring its categorisation with the narratives with traditions about the origin of a place. In Livy's narrative, while digging the foundations of a temple, an un-decomposed human head was found - a sign that Rome would be head of the world. The orientation in both stories is more cultural and historical, related to traditions about the origin of a place (and thereby to a collective fate and conception of history), as well as to the miraculous origin of the hero, the exceptional historical figure.

Regionally considered, neither the motif nor the belief is evenly distributed. They are quite common in the south of Serbia, and in the sources of Kosovo, Montenegro, and also Macedonia. An ethnological atlas ${ }^{1}$ also records data from central Serbia, but considerably more come from the south; in Kosovo the motif occurs both in Serb and Albanian sources, while data from northern Serbia are rare, as are also those in the sources of Croatians and Serbs from Croatia (Nožinić 1998: 72). In Macedonia, it has been recorded that some informers believe that fate is written in a notebook, but others hold that supernatural beings write on the head. The one who does not believe should dig a head from a grave and he will see the fate inscribed on it. Hence comes a proverb: "What is written on the head will happen over the head" (Cepenkov1972c: 45). There is even a ritual of leaving the writing tools near the baby when welcoming the Fates (Penushliski 1968: 303-309; Filipović 1939: 413-415). In neighbouring Bulgarians, where the idea of written fate is quite common (Sedakova 2007: 210) - which once again confirms its regional character - it is also believed that fate can be read after death: during the ritual washing of bones $^{2}$, individuals with supernatural gifts can see the writing on the skull (Sedakova 1994: 55-56; Miceva 1994: 10). Hence the sayings: "What is written on the head does not go on the stone" (Daskalova-Perkovska et al. 1994: 346); "That was written and destined for him (on the head)" (Sedakova 2007: 194). In fact, cranial bone joints are treated as a script (Sedakova 2007: 213). ${ }^{4}$ In Romania, this belief is not known, according to available data, but there is a saying that is obviously related to that idea: "Ce ţi-e scris în frunte ţi-e pus" (what is written for you, was put on your forehead). ${ }^{5}$ Likewise, it was believed in Serbia (Gornja Pčinja) that if a pigmentation or a freckle occurred on the nose on a newborn child on the third night after being born (when it is believed that the Fates come and their welcoming ritual occurs), it was proof of their arrival (Filipović \& Tomić 1955: 72). Similar to this is a belief from Leskovac, southern Serbia, that bloody scratches appear on a child's nose as a sign of their visit (Ethnological atlas, no. 2636). Bulgarians have the same belief in the signs on the nose, between the eyebrows (i.e., on the forehead), or on the chin. If a change in pigmentation 
occurs around the mouth, such as a rash or redness, or if moles appear on the skin, it is proof that the Orisnice (Bulg. the Fates) have 'spat upon', 'burned' or 'scalded' the child (Sedakova 2007: 212-213). These beliefs also exist in other nations of the Balkans. In Albania, the decision of fate is written on the forehead (Brednich 1964: 166). In Greece it is believed that the Fates, or mojre (Greek: Moirai, Roman: Parcae) write their decision on the forehead or the nose. If pigmentation appears on a child's skin, it is explained as mojra's writing (black pigmentation means bad luck, and white indicates good luck) (Brednich 1964: 162). Women take care not to wash off those stains or freckles on a child (Schmidt 1871: 212-213), and moles are called 'the writing of fate' (Lawson 1910: 126). A modification of the belief can be attributed to cultural and historical tradition: it was recorded that the Montenegrin duke Marko Miljanov had a white mark the size of a coin on his forehead, which was interpreted as a sign of greatness (Vukčević 1967: 17).

Geographically speaking it is clear that these beliefs and narrative motifs are more common in the south of Serbia, but that they are as common among Macedonians, Bulgarians, and Greeks, as they are rare among Croatians and Slovenians. Thus, it is reasonable to conclude that the occurrence is a Balkanism. Culturally and historically, this is the area of the Balkans which has been under strong Turkish and Muslim influence (Turkey conquered the Balkan states in the Middle Ages and remained there until the early 20th century, finally retreating in 1912. Thus the empire's influence on the material and spiritual culture, let alone on the lexicon, was hardly small). The idea that the motif of the writing of fate is "a late Balkanism formed on the basis of archaic concepts within Balkan linguistic alliance" (Dukova 1997: 79-80; Sedakova 2007: 211) ${ }^{6}$ is acceptable, but with the modification that will be shown in the following examples.

It is clear that there is a more general belief in written fate and another, a somewhat more specific one, related to writing fate on the forehead (or skull). The regional presence of this motif suggests looking for parallels primarily in Middle Eastern traditions. In the index of the Archive of Turkish Oral Narrative $\left(\right.$ Uysal-Walker) ${ }^{7}$ there is also a motif of fate written on the forehead. (The Eberhart-Boratav index does not mention it; however, this is not surprising since we are discussing a motif, not a tale type.) It is known in the Arabian tradition: in 1001 Nights it is mentioned several times (El-Shamy 2006: 187; Marzolph \& Van Leeuwen 2004: 111). ${ }^{8}$ In other Arabian tales it is identified as motif number A189.7 (the Deity ascertains the destiny of a newborn baby and inscribes it upon his forehead). Related motifs are found in A604§, A604.1§, A604.2§, A604.3§ (the determination of fate; tablets of fate; a quill records fate on a tablet of fate; 'it is written', i.e., fate, kismet) (El-Shamy 1995). This 
image exists in the beliefs and customs of Arabs; in addition, in keeping with the belief that a quill writes fate on heaven's tablet, it is believed that fate is written on everyone's forehead (proverb: 'What is written on the forehead will inevitably be witnessed by the eye', i.e., it will be recognised) (El-Shamy 2008: 25). El-Shamy states that the oldest mention of written fate occurs in ancient Egyptian literature (Maspero 2002: $\mathrm{xl}$ ) ${ }^{9}$ and although this also depends on the given translation from Egyptian, it is not related to writing on the forehead. However, it does appear among Moroccan Jews. ${ }^{10}$ And in Persian the word meaning 'forehead' (pišāni) also, although more rarely, means 'fate', 'luck', or 'fortune'; hence the saying: pišāni dāštan (have luck, be successful); pišāniboland means 'with a high forehead' and 'successful', 'lucky'. The word sarnevešt - fate, predestination - literally means 'written on the head' (PRS 1983 [1970]). ${ }^{11}$ In Persian folktales, however, the motif does not have a prominent position. ${ }^{12}$ On the other hand, it occurs in Persian classics: in Nizami's Iskandar namah (II: 24), as well as in Omar Khayyám's Rubaiyat (to be sar-e man nebešte-i, man che konam ('you / the God / wrote on my forehead, what can I do?')) (Khayyam 2004: 120-121). ${ }^{13}$ But in these it may have been borrowed from the Arabic culture. The image also appears in the pre-Islamic civilisations of Iran: in the 5th century, Armenian Christian writer Yeznik polemicised against the fatalism of the Zoroastrian doctrine (it seems that the fatalism of the Zoroastrian doctrine was developed especially in the Pehlevi period) and mentioned the idea of fate written on the forehead (Dhalla 1938: 338). Also, in Armenian, the expression tsakatagir carries the same meaning. Outside this range, I am familiar only with the Latvian belief that if a woman has wrinkles on her forehead it means that she will become a widow (Šmits 1940: 1439). ${ }^{14}$

All this suggests the Eastern origin of the motif. However, it seems that its ultimate source does not belong to the Islamic cultural region. Its roots are older and are related to the oldest testimonies found in ancient Indian tales. In Pañcatantra and Hitopadeśa it is repeated a number of times:

likhitam api lalāte projjhitum kah samarthah

Who can delete what is written on the forehead (Hitopadeśa 1957: 1, 19)

vidhātrā racitā yā sā lalāte’kșaramālikā na tām mārjayitum śaktāḥ svaśaktyāpy atipaṇditāḥ

Letters on the forehead written by fate cannot be erased by all the sages with their (magical) force

(Pañcatantra 1991: 2, 180) 
yat yasya likhitam dhātrā lalātakșarapan்ktiṣu

tat avaśyam asambhāvyam api taysa upatiṣthate

What is written for someone in lines of letters on the forehead by the god of fate will inevitably happen to him

(Somadeva 1970: 12, 19, 156)

hariṇā 'pi hareṇa 'pi brahmaṇā 'api surāir api

lalātalikhitā rekhā parimārșțum na śakyate

Not Hari (Vishnu/Narayana) nor Hara (Shiva) nor Brahmā nor gods can erase what is written on the forehead

(Vikramacarita 1926: 22, 4) ${ }^{15}$

It is said in one aphorism (Subhāşita) in a humorous tone:

itaratāpaśatāni yadṛcchayā

vitara tāni sahe caturānana

arasikeșu rasatvanivedanam

śirasi mā likha mā likha mā likha

O Brahma! Assign me hundreds of other miseries, as you wish. That I might tolerate. But please do not write on my forehead that I will have to read poetry to those who cannot appreciate it

(Das 2004: 81)

Poet Bhartrhari says:

Yad dhātrā nijabhālapațtalikhitam stokam mahad vā dhanam

Tat prāpnoti marusthale 'pi nitarām merau ca nāto 'dhikam

Whatever wealth, vast or scant, is traced

On a man's brow by Disposer Brahma

Will he win though he dwells on a barren desert

But no more on the golden mountain Meru

(Bhartrhhari 1967: 44-45)

In Kṛṣnamiśra's drama Prabodhacandrodaya, a similar imagery appears:

mrtyur nrtyati mūrdhni

Death is dancing on your forehead

A servant replies to a given command:

mūrdhni niveśitah sarvā evājnah

All your commands are inscribed upon my forehead

(Kṛ̣nạamiśra 1974: 260) 
The expression brahmarekha is also recorded in Sanskrit. It is defined by the well known Monier-Williams dictionary as "Brahma's line; the lines of a man's destiny supposed to be written by Brahma on the forehead of a child on the sixth day after its birth". A later Muslim influence can be excluded since the tales are firmly rooted in Hinduist culture and a major part of these examples are older than the arrival of Islam in India (Pañcatantra 3rd-6th century; Hitopadeśa 9th-14th century; Bhartṛhari supposedly 7th century). Examples from artistic literature should not be taken as a source, but rather as a testimony of the existence of the motif. A collection of tales such as Pañcatantra, although written in Sanskrit and in the high culture, derives from oral tradition. ${ }^{16}$ This is confirmed by later records of Indian folktales. In the Motif Index of Folk Literature Stith Thompson includes the Indian variants for the motifs: "Man's fate written on his skull" (M.302.2), "Fate written on the head" (M.302.2.1), "Personification of Good Luck lives in man's forehead" (N.113.2). In the review of Indian folktales, which Thompson wrote with Jonas Balys, he enlists motifs of fate written on the forehead or skull (Thompson \& Balys 1958). As here he addresses the modern Indian folklore that originates with modern Indian languages, we can identify a continuity in oral tradition as well as a continuity of beliefs in that area (Day 1912: 9; Narayan 1997: 144; Roy 2001 [1985]: 290-291). In modern folklore, the motif can be fitted into different narratives (the goddess of fate, Shashthi, writes on the prince's forehead on the sixth day after his birth that he will subsist on hunting. A minister hears about this and tries to prevent that. Or, Brahman writes on the prince's forehead that he will get married when he is twelve years old and later die from a thunder bolt (Cosquin 1922: 136-137).

In India this motif is also often related to folk beliefs. It was recorded by early ethnographers in the 19th century (Dubois 2007: 614-615; Bacheler 1856: 108) as well as by contemporary field researchers (Basu \& Bose 2005: 194; Wadley 1994: 119, 122). The belief that the Creator writes fate on the forehead (MonierWilliams 1891: 370) is generally accepted. Although Monier-Williams (ibid.) states that there is no knowledge about these rituals, they do exist, and are recorded in modern India. In Bengal and Maharashtra the sixth day after birth is considered especially critical and is devoted to Goddess Shashthi. The ritual that is preformed is not of orthodox Hindu origin, but is obviously folk-magical, with the aim of protecting the child and ensuring him or her a long life. The goddess herself is of folk origin, incorporated into Hinduism, and is primarily the protector of birth and children. In the evening, an inkwell with red ink and a quill are placed in the child's crib, so that the god of fate, Vidhata Purusha, may write faith on the child's forehead. Women stay awake with a burning lamp all night (Gangulova 1969: 272). These beliefs and rituals are also present in 
Tamil (Jackson 2005: xxii) and have been incorporated into Sikhism (in the holy scripture Granth Sahib) (Rahi 1999: 50-59).

Recent research confirms the presence in non-Indo-European as well as in Indo-European cultures, in the folktales, beliefs and phraseology of Indian languages (apart from Sanskrit, also in the Hindu, Tamil, Marathi and Kannada languages) (Kent 2009). For this reason, in Oriental studies, it is accepted that the Arabic belief about fate on the forehead is of Indian origin (Cohen-Mor 2001: 7-8). Based on this data, the source of the motif can be determined, as well as the ways of its transmission to Balkan cultures.

We cannot but wonder why precisely the forehead. The forehead is a significant part of the body in other folk prose genres as well. In fairytales, a wonderful beauty or her children have a star on the forehead. In some cases, the outer soul of an opponent hidden in an egg can be destroyed only if an egg is broken on the opponent's forehead. Another 'simple form' (in Jolles' sense) has to be taken into consideration, a saying which in the Serbian language goes: 'it is (not) written on his forehead' (meaning: it is not written on one's forehead what is in them). This expression, which from a folkloristic perspective is defined as a saying, would be defined as a phraseologism from a linguistic point of view. In contemporary speech, the phraseologism is not used to represent fate, but rather to express other ideas: 'It is not written on his forehead what he is like; it is not written on his forehead whether he has money'. Examples from speech praxis show the possibility of using these words in the most different of contexts. This expression also exists in German (es steht ihm auf der Stirn geschrieben), in Latvian, and also in the Latin language (fronti nulla fides ${ }^{17}$; ex fronte perspicere). Cicero, talking to his opponents, suggests in his famous speech against Catiline: "[---] sit denique inscriptum in fronte unius cuiusque, quid de re publica sentiat" ('Lastly, let it be inscribed on the forehead of each one what he thinks about the state') (Cicero I: 32). In English the closest expression is 'written all over the face', meaning: 'obvious from someone's expression or countenance', used for guilt, greed, joy, etc. (Wilkinson 1992: 406).

What is the connection between this phrase and the belief/motif of fate on the forehead? The origin of the phrase has not been conclusively established. For example, it is assumed that the Russian expression "na lbu napisano" ('written on the forehead') originates from the penal custom of branding offenders (first on the cheek, and from 1746 on the forehead). The mark sometimes had the form of a letter and powder was rubbed on it to make it more visible (Birikh \& Mokienko \& Stepanova 1998: 344-345). The opposite phrase 'na lbu ne napisano' ('it is not written on the forehead') is used in a comic sense according to the same interpretation. Similar to this is the custom of cattle branding, i.e., marking property, placing a mark. The word 'mark' (beleg) and the idea of marking are 
used in southern Slavic folk culture for people who are branded in some way: a group of southern Slavic proverbs and expressions, the metaphoric expression of storytelling, is dedicated to those who are 'marked', i.e., to people 'marked' with a sign (Sedakova 2007: 72-73; 82). ${ }^{18}$ Negative stereotypes are applied to the marked ones in traditional culture, e.g., men without a beard and moustache, ${ }^{19}$ or sick people and other misfortunates who are considered to be marked by God and who should be avoided. (There is data about Balkan Christians who sometimes tattooed a cross on their children's foreheads to prevent them from being recruited for the Janissaries). This interpretation also has biblical parallels: Yahweh puts a mark (ot) on Cain so that he would not be killed (Genesis 4: 15), although it is not specified what kind of sign it was or where it was placed. In Ezekiel (9: 4) a sign on the forehead is written by Yahweh's envoys. In the Book of Revelation (17: 5) the sinful woman is described in this way: "On her forehead was written a secret name: BABYLON the GREAT, THE Mother of Prostitutes and Detestable Things of the Earth"; it also says (13: 16): "The second beast forces all people - important and unimportant, rich and poor, free and slaves - to be marked on their right hands or on their foreheads". ${ }^{20}$ These examples are clearly not related to fate. In the Jewish and Christian tradition they fit into a religious context, in which instead of fate God acts, or the Antichrist, as his earthly imitator. However, it is not certain that the idea of fate written on the forehead lies in direct connection with this version of the phraseologism, and therefore with the idea of placing a mark. Although it is possible that the saying can be related to this mark - because phraseologisms keep long gone customs (Permyakov 1970: 49) ${ }^{21}$ - the phraseological idea itself can be older and independent of an actual punishing ritual: it can be a simple observation of the expression of feelings (this is very evident in the English expressions relating to the face, and Cicero's example can be interpreted as a mark as well as an observation of what people think).

One facet that these expressions have in common is a relationship between the outer and the inner, concerned with man's virtues, and especially character. The negative side, which is more common, actually denies the primary belief in the possibility of reading from the forehead. One's character remains concealed, and the expression is based on a certain degree of rationalism. In the background of the 'positive' form of the phrase lies the folk idea that one's character can be seen from the outside. This is especially evident in fairy tales, in which good heroines are beautiful and the evil are ugly (Lüthi 1990: 41-42). ${ }^{22}$ The pictorial way of thinking is denied in the modern phrase ('it does not say so on the forehead'). Character will be replaced by other elements in contemporary speech, which shows a surprising agility and ability to fit this statement into the contemporary period and contemporary speech. Although the idea about 
fate written on the forehead is in some way connected to this folksy way of thinking, it obviously has another history: it is constrained, specialised, and connected to belief, indicating that it is different than the general idea about anything on the forehead. Its connection to fate and faith probably derives from India and from there it spread through the Muslim Orient and into the part of the Balkans which was under Muslim influence. Belief is inserted as a motif into tales and traditions about fate.

In the end, we will mention that reading of the future from signs on the body in European learned magic is still present, with palmistry as the best known example. There are others, such as metoposcopy - predicting a person's destiny by reading the lines on the forehead. Lines are, according to the principle of analogy ${ }^{23}$, related to different planets, and with a correct reading the future can be told, as well as one's character. In 1648, Philippo Finella published a book about metoposcopy (De Metroposcopia); in 1637 Ciro Spontini (Seligman s.a.: 301-306) published a book on the same subject. Reading the character from the face - which later on evolved into physiognomy (J. C. Lavater being the best known example $)^{24}$ - brings these examples of learned magic close to the folk belief and contemporary phraseologisms, but it is still to be determined whether there is a direct link/relationship, or whether the folk idea has entered into the learned magic, or again, whether the popular editions of these books influenced the strengthening of the existing idea, and even a diffusion. Metoposcopy was also known in Jewish circles that practiced Lurianic Kabbalah (Fine 1986). As there is certainly a similarity to chiromancy (reading a person's character or future from the lines on the palm), maybe there is some connection between the visual aspect of the phrase and the belief about fate lying in the lines on the forehead. Like the Rorschach test, they may provoke the idea, or, in other words, attract an already existing idea. A similar mechanism operates within etiological and historical legends, in which an object with its shape or oddness (a rock or a turtle) provokes narration, after which the object itself is presented as proof of the truthfulness of the narration. In general, chiromancy is very rare as a narrative motif, although there is the following example from Macedonian literature: Christ tells the teacher to look at the palms of the children, for their fate can be seen there (Cepenkov 1972b, no. 208).

It is reasonable to ask whether this kind of research - leaving aside the Balkanological and Slavic aspects - might be charged with old-fashionedness, i.e., are old Benfey's and Cosquin's methods being renewed? Certainly, in terms of methodology it does not aim to revive the 19th-century theories. It seems - if this kind of work can derive some more general conclusions - that the following can be observed. Philological research is far from being exhausted, so the study of folklore still has its place in literary and linguistic studies. This can be noted 
in the justification of the use of old written testimonies, i.e., literature of the ancient cultures, taking them as a testimony, not as a source. Migrations and the contacts that they brought about - which have never been contradicted although they have not been the methodological focus for decades - can be seen in a different light (which the old migrationism underestimated): the interactions between cultural zones and the consequent discerning of cultural regions may be investigated. It is necessary to emphasise the link between motif and belief, because, although it has migrated, the motif was accepted in some areas and it has continued to live for centuries, obviously because it is connected with belief and fulfils a more significant function than purely narrative. A comparison of the different simple forms, such as sayings and tales, in this case fully reveals the phenomenology of both only in terms of its philological and ethnological cultural background.

\section{NOTES}

1 Unfinished project; data are kept in the archive of the Ethnographic Museum in Belgrade.

2 A ritual that is characteristic of Slavic culture but is not present in other Indo-European people.

3 Comment for type 934B.

${ }^{4}$ We could ask whether this simple empirical observation is the origin of the motif itself or its subsequent acknowledgement.

5 Annemarie Sorescu-Marinković (Institute for Balkan Studies, Serbian Academy of Sciences and Arts) has kindly assisted with Romanian beliefs.

6 This could be applied to the writing on the forehead, not to writing in books; but it seems that writing on the forehead also originates in the Orient.

7 http://aton.ttu.edu, last accessed on September 9, 2014.

$8 \mathrm{Cf}$. the motif of magical writing on the forehead (ibid.: 212).

9 I am grateful to Professor El-Shamy for sharing his thoughts with me and for providing literature that is not easily available.

${ }^{10}$ Motif 302.2.2 in AaTh 934F (a daughter is born with three stars on the forehead, which indicates that she will be a thief, beggar and prostitute) (Palacin de Arcadio 1952-1953).

${ }^{11}$ Persidsko-russkii slovar' (Persian-Russian Dictionary) I-II. There is an interesting comparison for the observations about the mark on the forehead: $u$ mesle gave-pišanni sefid ast ('he is like a cow with a white mark on the forehead', i.e., he is known to everyone). 
${ }^{12}$ According to Professor Marzolph of the Enzyklopädie des Märchens in Göttingen, Germany, to whom I am grateful for help.

${ }^{13}$ In Saadi's Golestan (1st chapter, 5th tale) a courtier is mentioned who has had signs of greatness on the forehead since his childhood.

${ }^{14}$ I am grateful to Sandis Laime from the Archives of Latvian Folklore, Institute of Literature, Folklore and Art, of the University of Latvia, for the data.

${ }^{15}$ Southern recension.

${ }^{16}$ More about that in Grintser 1963.

${ }^{17}$ Cf. Iuvenalis, Saturae II: 8.

${ }^{18}$ In Serbian and Bulgarian there are phraseologisms 'roll over the head' - 'to get around'; 'swoop down on the head' - 'to put all the blame on someone'; 'it came on his head' 'he had to do something for someone'; 'to put a head in a bag' - 'to risk one's neck', which Sedakova connects with this idea, i.e., with the connection of the forehead/head with written fate. This is a much wider idea in which the head is considered to be the focus of one's life, i.e., metonymically as Man himself ('how many heads' = 'how many people'; 'man's head' = man, 'woman's head' = woman), so it probably has nothing to do with the writing on the forehead.

19 There are a number of tales about Cosa (the Beardless One), who is either a villain or a victim of a prank in the folklore of Balkan people; according to older assumptions it derives from stereotypes of eunuchs, who were influential and detested in Byzantium and Turkey, but it has more to do with hostility to someone with the "mark", i.e., someone who stands out from the image of the ideal man.

${ }^{20}$ In a religious context, the Jewish custom of placing the scrolls of parchment on the forehead (tefillin) can be mentioned, or the Athonite custom of writing a name on the skull of a dead monk. Akin is the Jewish tradition about the golem, who becomes alive when a magical inscription is put on his forehead.

${ }^{21}$ A reminder: writing on the forehead belongs to living beliefs.

${ }^{22}$ For older scholars like Karl Spiess, this was proof that fairytales originate from undeveloped culture (Spiess 1924: 17, 103).

${ }^{23}$ The principle of analogy is one of the key principles of esoteric thinking, as defined by Antoine Faivre.

${ }^{24}$ According to the data that were kindly given to me by Sang Hun Kim (University of Seoul), in South Korea physiognomics is still active. There is no belief about fate on the forehead, but there is one about fate in the lines of the face. 


\section{REFERENCES}

Bacheler, O.R. 1856. Hinduism and Christianity in Orissa. Boston: G.C. Rand \& Avery. Basu, Tara Krishna \& Bose, Basanta Coomar 2005. Village Life in Bengal / Hindu Customs in Bengal. Edited by Richard Stevenson. Philadelphia: Xlibris Corp.

Bhartihari 1967. Poems. Transl. by B. Stoler Miller. New York: Columbia University Press.

Birikh, Aleksandr \& Mokienko, Valerii \& Stepanova, Liudmila 1998. Slovar' russkoi frazeologii. Istoriko etimologicheskii spravochnik. [The Dictionary of Russian Phraseology: Historical-Etymological Handbook.] Sankt-Peterburg: Folio Press.

Brednich, Rolf-Wilhelm 1964. Volkserzählung und Volksglaube von den Schicksalsfrauen. FF Communications 193. Helsinki: Academia Scientiarum Fennica.

Cepenkov, Marko 1972a. Makedonski narodni umotvorbi 3: Narodni prikazni. Volšebni prikazni. [Macedonian Folk Literature 3: Folk Tales. Fairy Tales.] Skopje: Matica makedonska.

Cepenkov, Marko 1972b. Makedonski narodni umotvorbi 4: Narodni prikazni. Legendi. [Macedonian Folk Literature 4: Folk Tales. Legends.] Skopje: Matica makedonska.

Cepenkov, Marko 1972c. Makedonski narodni umotvorbi 9: Narodna veruvanja. Detski igri. [Macedonian Folk Literature 9: Folk Beliefs. Children's Games.] Skopje: Matica makedonska.

Cicero I = Cicero Marcus Tullius 63 B.C. Oratio in L. Catilinam Prima. Available at http:// www.thelatinlibrary.com/cicero/cat1.shtml, last accessed on September 9, 2014.

Cohen-Mor, Dalya 2001. A Matter of Fate: The Concept of Fate in the Arab World as Reflected in Modern Arabic Literature. New York: Oxford University Press.

Cosquin, Emmanuel 1922. Les contes indiens et l'Occident. Paris: Champion. Available at https://archive.org/details/lescontesindiens00cosquoft, last accessed on September 4, 2014.

Das, Sadananda (ed.) 2004. Subhāşita-Mañjarī. Allahabad: Padmaja Prakashan.

Daskalova-Perkovska, L. \& Dobreva, D. \& Koceva, J. \& Miceva, E. 1994. B’lgarski folklorni prikazki. [Bulgarian Folk Tales.] Sofia: Universitetsko izdv-o Sv. Kliment Ohridski.

Day, Lal Behari 1912. Folk-Tales of Bengal. London: Macmillan. Available at https:// archive.org/details/folktalesofbenga00dayl, last accessed on September 4, 2014.

Dhalla, Maneckji Nusserwanji 1938. History of Zoroastrianism. New York: Oxford University Press. Available at http://www.avesta.org/dhalla/dhalla1.htm, last accessed on September 4, 2014.

Đorđević, Dragutin 1988. Srpske narodne pripovetke i predanja iz leskovačke oblasti. [Serbian Folk Tales and Legends from the Leskovac Region.] Beograd: Srpska akademija nauka i umetnosti.

Dubois, Abbé J.A. 2007. Hindu Manners, Customs and Ceremonies. New York: Cosimo.

Dukova, Ute 1997. Die Bezeichnungen der Dämonen in Bulgarischen. München: Verlag Otto Sagner.

El-Shamy, Hasan M. 1995. Folk Traditions of the Arab World: A Guide to Motif Classification. Vol. 1. Bloomington: Indiana University Press. 
El-Shamy, Hasan M. 2006. A Motif Index of The Thousand and One Nights. Bloomington, Ind: Indiana University Press.

El-Shamy, Hasan M. 2008. Religion Among the Folk in Egypt. Westport, CT \& London: Praeger.

Filipović, Milenko S. 1939. Običaji i verovanja u Skopskoj kotlini. [Rituals and Beliefs in Skopje Valley.] Beograd: Srpska kraljevska akademija.

Filipović, Milenko S. \& Tomić, Persida 1955. Gornja Pčinja. Beograd: Naučna knjiga.

Fine, Lawrence 1986. The Art of Metoposcopy: A Study in Isaac Luria's Charismatic Knowledge. AJS Review, Vol. 11, No. 1, pp. 79-101. http://dx.doi.org/10.1017/ S0364009400001525.

Gangulova, M. 1969. Prazdniki zhiznennogo tsikla. [Feasts of Life Cycle.] In: Dushan Zvavietel (ed.) Bogi, brakhmany, liudi: chetyre tysiachi let induizma. [Gods, Brahmans, Men: 4000 Years of Hinduism.] Moskva: Nauka, pp. 267-284.

Grintser, Pavel 1963. Dreuneindiiskaia proza. [Ancient Indian Prose.] Moskva: Izdatel'stvo vostochnoi literatury.

Hitopadeśa 1957 = Hitopadeśa by Nârâyaṇa, ed. by M.D. Apte. Poona: Aryabhushan Press.

Jackson William J. 2005. Vijayanagara Voices: Exporing South Indian History and Hindu Literature. Aldershot \& Burlington: Ashgate.

Javor 1882 = Narodne pripovetke iz Slabinje kod Bosanske Kostajnice. [Folk Tales from Slabinja to Bosanska Kostajnica.] Javor (magazine), pp. 1561-1563.

Kent, Eliza F. 2009. What's Written on the Forehead Will Never Fail: Karma, Fate, and Headwriting in Indian Folktales. Asian Ethnology, Vol. 68, No. 1, pp. 1-26. Available at http://www.asia-studies.com/2AsianEthnology09.html, last accessed on September 5, 2014.

Khayyam, Omar 2004. Rubaiyat. Translated by N. Tomić-Drašković \& Ž. Akopdžanjan. Belgrade: Cultural Centre of Islamic Republic Iran.

Krsnamisra 1974 = Le Prabodhacandrodaya de Krsnamisra: un drame allégorique Sanskrit (texte traduit et commenté par Armelle Pédraglio). Paris: Institut de Civilisation Indienne.

Lawson, John C. 1910. Modern Greek Folklore and Ancient Greek Religion: A Study in Survivals. Cambridge: University Press. Available at https://archive.org/details/ moderngreekfolkl00laws, last accessed on September 5, 2014.

Livy, Titus. Ab urbe condita. Available at http://www.gutenberg.org/ebooks/19725; http:// www.thelatinlibrary.com/livy/liv.1.shtml\#55, last accessed on September 9, 2014.

Lüthi, Max 1990. Das Volksmärchen als Dichtung. Ästhetik und Antropologie. Göttingen: Vandenhoeck \& Ruprecht.

Marzolph, Ulrich \& van Leeuwen, Richard 2004. The Arabian Nights Encyclopedia, Volume 1. Santa Barbara, CA: ABC Clio.

Maspero, Gaston 2002. Popular Stories of Ancient Egypt (ed. \& introd. by Hassan ElShamy). Santa Barbara, CA: ABC-CLIO. Available at http://phillipkay.files. wordpress.com/2011/03/tales-of-ancient-egypt1.pdf, last accessed on September 5, 2014.

Miceva, Evgenia 1994. Nevidimi noshtni gosti. [Invisible Night Guests.] Sofia: Nauka i Iskusstvo. 
Milošević-Đorđević, Nada 1971. Zajednička tematsko-sižejna osnova srpskohrvatskih neistorijskih epskih pesama i prozne tradicije. [Mutual Thematic-Syuzhetic Basis of Serbo-Croatian Epic Poems and Prose Tradition.] Beograd: Faculty of Philology, Beograd University.

Monier-Williams, Monier 1891. Brahmanism and Hinduism: Or, Religious Thought and Life in India. London: J. Murray. Available at https://archive.org/details/ brhmanismandhin01wilgoog, last accessed on September 5, 2014.

Nahshabi 1979 = Nakhshabi, Ziia ad-Din. Kniga popugaia (Tuti-name). [Tales of a Parrot.] Transl. by E. Bertels. Moskva: Nauka.

Narayan, Kirin 1997. Moondays on the Dark Night of the Moon: Himalayan Foothill Folktales. New York: Oxford University Press.

Nizami. Iskandar-nāmah. Available at http://persian.packhum.org/persian//main, last acessed on September 10, 2014.

Nožinić, Dražen 1998. Mitološka bića koja određuju sudbinu deteta. [Mythic Creatures That Determine the Fate of Children.] Raskounik, Vol. 93-94, pp. 71-78.

Palacin de Arcadio, Larrea 1952-1953. Cuentos populares de los judios del Norte de Marruecos. Tetuán: Editora Marroquí.

Pañcatantra 1991. Edited by Ramchandra Jha. Vārāṇasī: Caukhambā Vidyābhavana. Available at http://ignca.nic.in/sanskrit/pancatantra.pdf, last accessed on October 14, 2014.

Penushliski, Kiril 1968. Narečnicite vo makedonskoto narodno tvoreštvo. [Fates in Macedonian Folk Literature.] In: Rad XIII-og kongressa saveza folklorista Jugoslavije u Dorjanu 1966. Godine. [Papers of the 13th Congress of the Association of Yugoslavian Folklorists in Dorjan.] Skopje: Savez folklorista Jugoslavije, pp. 303-309.

Permyakov $1970=$ Permiakov, Grigorii. Ot pogovorki do skazki. [From Saying to Tale.] Moskva: Nauka.

PRS 1983 [1970] = Persidsko-russkii slovar' I-II. [Persian-Russian Dictionary I-II.] Moscow: Russkii iazyk.

Rahi, Hakim Singh 1999. Sri Guru Granth Sahib Discovered: A Reference Book of Quotations. Delhi: Motilal Banarsidass Publishers.

Röhrich, Lutz 1964 [1956]. Märchen und Wirklichkeit. Wiesbaden: F. Steiner.

Roy, Pranab Chandra Chaudhury 2001 [1985]. Best Loved Folk Tales of India. New Delhi: Sterling Publishers.

Schmidt, Bernhard 1871. Das Volksleben der Neugriechen und das hellenische Althertum. Leipzig: B.G. Teubner.

Sedakova, Irina 1994. Balkanoslavianskie predstavleniia o demonakh sud'by: transformatsii vo vremeni i v prostranstve. [Balkan-Slavic Conceptions about Fate Demons: Transformations of Time and Space.] In: Irina Sedakova (ed.) Vremia $v$ prostranstve Balkan. [Time in Balkan Space.] Moskva: RAN, pp. 42-63.

Sedakova, Irina 2007. Balkanskie motivy v iazyke $i$ kul'ture bolgar. [Balkan Motifs in Bulgarian Language and Culture.] Moskva: Indrik.

Seligmann, Kurt s.a. Das Weltreich der Magie: 5000 Jahre Geheime Kunst. Wiesbaden: Löwit. 
Somadeva, Bhatṭa 1970. Kathāsaritsāgara. Ed. by Jagadīś Lāl Śāstri. Delhi: Motilal Banarsidass.

Spiess, Karl 1924. Das deutsche Volksmärchen. Leipzig: B.G. Teubner.

Šaulić, Novica 1931. Srpske narodne priče. [Serbian Folk Tales.] 1/III. Beograd: Knjižarnica Gece Kona.

Šmits, Pēteris (ed.) 1940. Latviešu tautas ticējumi III. [Latvian Folk Beliefs.] Rīga: Latviešu folkloras krātuve.

Thompson, Stith \& Balys, Jonas 1958. The Oral Tales of India. Bloomington: Indiana University Press.

Veljić, Mihailo 1900. Srpske narodne umotvorine, običaji i verovanja iz Debra i okoline. [Serbian Folk Literature and Beliefs from Debar and Its Surroundings.] Brastvo, Vol. 9-10, pp. 378-449.

Vikramacarita 1926 = Vikrama's Adventures or The Thirty-Two Tales of the Throne, Part 2. Edited by Franklin Edgerton. Cambridge, MA: Harvard University Press. Available at http://titus.uni-frankfurt.de/texte/etcs/ind/aind/klskt/vikrama/vikramsr/ vikra.htm, last accessed on October 16, 2014.

Vukčević, Mihailo 1967. Istinita legenda. [True Legend.] In: Marko Miljanov (ed.) Sabrana djela 5. [Complete Works 5.] Titograd: Grafički zavod.

Wadley, Susan Snow 1994. Struggling With Destiny in Karimpur 1925-1984. Berkeley: University of California Press.

West, Martin Litchfield 2007. Indo-European Poetry and Myth. Oxford \& New York: Oxford University Press.

Wilkinson, Peter Richard 1992. Thesaurus of Traditional English Metaphors. London \& New York: Routledge. 